\title{
Cytogenetic analysis of horse oocytes matured in vitro for different periods of time
}

\author{
J Sosnowski *, D Lechniak, M Brzozowska, M Świtoński \\ Department of Genetics and Animal Breeding, Agricultural University of Poznań, ul Wolyńska 33, \\ 66-637 Poznań, Poland
}

(Received 5 July 1996; accepted 15 September 1996)

\begin{abstract}
Summary - This paper presents the results of recovering horse oocytes by aspiration and maturation in vitro for $24,30,36$ or $42 \mathrm{~h}$. A total of 522 oocytes were recovered from 221 ovaries (2.4 per ovary) and 271 oocytes $(51.9 \%)$ were selected for in vitro maturation (IVM). Oocytes were cultured in maturation medium (TCM $199+$ estrus cow serum $[$ ECS] + folliclestimulating hormone $[\mathrm{FSH}]+17 \beta$-estradiol + gentamycin). One hundred and seventy oocytes were cytogenetically analysed $(68.3 \%)$. Cytogenetic analysis showed that the stage of maturation (first telophase-TI or second metaphase-MII) for fertilization was achieved in $42.2 \%$ of oocytes after $24 \mathrm{~h}, 70.4 \%$ of oocytes after $30 \mathrm{~h}, 75.0 \%$ of oocytes after $36 \mathrm{~h}$ and $74.4 \%$ of oocytes after $42 \mathrm{~h}$ of in vitro maturation.
\end{abstract}

\section{horse oocyte / in vitro maturation / cytogenetic analysis}

Résumé - Analyse cytogénétique des ovocytes équins venant à maturité in vitro en diverses périodes de temps. Au total, on a recueilli 522 ovocytes de 221 ovaires équins (en moyenne 2,4 ovocytes pour un ovaire). On a sélectionné 271 ovocytes $(51,9 \%, 271 / 522)$ pour la maturation in vitro, effectuée dans l'atmosphère de $5 \%$ de $\mathrm{CO}_{2}$ et à température de $38,5^{\circ} \mathrm{C}$, dans les gouttes $(50 \mu \mathrm{L}$ chacune) d'agent de maturation (TCM 199 avec $20 \%$ de sérum bovin de sut, $2 \mu \mathrm{g} / \mathrm{mL}$ de FSH, $1 \mu \mathrm{g} / \mathrm{mL}$ de $17 \beta$-estradiol et $50 \mu \mathrm{g} / \mathrm{mL}$ de gentamycine) sous la paraffine. La maturation in vitro a été effectuée pendant $24,30,36$ ou 42 heures. À la fin de la maturation in vitro, on a fait des préparations cytogénétiques de 249 cellules $(91,9 \%, 249 / 271)$ par la méthode « air drying ». On a effectué l'analyse cytogénétique de 170 ovocytes $(68,3 \%$, 170/249). On a constaté que le pourcentage d'ovocytes qui ont atteint la maturité de fécondation (télophase I ou métaphase II) dépendait du temps de culture in vitro et était de 42,2 ( 24 heures), 70,4 (30 heures), 75,0 (36 heures) et 74,4\% (42 heures). Les résultats obtenus montrent qu'une grande partie des ovocytes équins atteint la maturité de fécondation 30 heures au minimum après la culture in vitro.

ovocyte équin / maturation in vitro / analyse cytogénétique

* Correspondence and reprints.

Tel: (48) 614872 50; fax: (48) 614871 46; e-mail: jarys@jay.au.pozman.pl 


\section{INTRODUCTION}

In vitro maturation (IVM) of preovulatory oocytes obtained from ovaries of slaughtered animals followed by in vitro fertilization (IVF) has become a source of embryos for embryo transfer (ET) and genetic experiments (eg, transgenesis and cloning). In cattle it is possible to produce viable embryos at morula and blastocyst stages with a success rate of 25-50\% (Gordon, 1994). In the mare, however, the development of IVM/IVF procedures still presents difficulties. This is due in part to the limited number of oocytes that it is possible to recover from an ovary (Hinrichs, 1991). In cattle and pigs follicle aspiration seems to be the method of oocyte recovery, resulting in a sufficient number of oocytes acceptable for IVM (Gordon, 1994; Sosnowski et al, 1996). The aspiration technique used for collecting equine oocytes has not given similar results (Choi et al, 1993; Alm and Torner, 1994). Slicing of ovaries followed by follicle isolation has produced a higher number of collected oocytes of good quality (Zhang et al, 1989; Choi et al, 1993). However, this method requires intensive labour and skills and is very time-consuming.

The time required for maturation of equine oocytes has been reported by many investigators but the results varied among their studies (Fulka and Okólski, 1981; King et al, 1990; Willis et al, 1991a,b, 1994; Hinrichs et al, 1993; Alm and Torner, 1994; Del Campo et al, 1995). Nevertheless, it is known that the maturation time in the horse is longer than in cattle, sheep and goats, which is about $24 \mathrm{~h}$ (Gordon, 1994). In the studies of Del Campo et al (1990) and Zhang et al (1990) equine IVF embryos have been produced from oocytes matured for $36-48 \mathrm{~h}$. In the present study the time required for oocyte maturation was examined.

\section{MATERIALS AND METHODS}

Mare ovaries were collected within $15 \mathrm{~min}$ of slaughter in an slaughterhouse in Rawicz
(Poland). Ovaries were washed in water at $30^{\circ} \mathrm{C}$, placed in saline solution in plastic bags and transported to the laboratory within $2-3 \mathrm{~h}$. In the laboratory, the ovaries were washed in fresh saline $\left(37^{\circ} \mathrm{C}\right)$ and cumulus oocytes complexes (COCs) were aspirated from follicles of $5-20 \mathrm{~mm}$ in diameter. Low pressure (about -0.1 bar) as created by a water pump was used as described by Berg and Brem (1991). The cylinder containing follicular fluid with oocytes was kept at $37^{\circ} \mathrm{C}$ for $10 \mathrm{~min}$. The pellet of the COCs was then removed from the bottom of the cylinder and transferred to a petri dish with collecting medium (TCM $199+10 \%$ estrus cow serum $[\mathrm{ECS}]+50$ $\mu \mathrm{g} / \mathrm{mL}$ gentamycin [Polfa, Tarchomin, Poland]). The COCs were selected for IVM under a stereomicroscope (at $100 \mathrm{x}$ magnification). Only immature oocytes with dark, evenly granulated ooplasm and at least one layer of compact, intact cumulus cells were accepted for IVM (Alm and Torner, 1994). The selected COCs were washed three to four times in collecting medium which was followed by a final washing in maturation medium (TCM $199+20 \% \mathrm{ECS}+2 \mu \mathrm{g} / \mathrm{mL}$ follicle-stimulating hormone $[\mathrm{FSH}]$ [Sigma, Saint Louis, MO, USA] $+1 \mu \mathrm{g} / \mathrm{mL} 17 \boldsymbol{\beta}$-estradiol [Sigma] $+50 \mu \mathrm{g} / \mathrm{mL}$ gentamycin [Polfa]) and transferred to the droplets of MM.

The oocytes were matured in groups of five to ten under parraffin oil in $50 \mu \mathrm{L}$ maturation droplets at $38.5^{\circ} \mathrm{C}$ in $5 \% \mathrm{CO}_{2}$ in humid air. The IVM process was conducted for $24,30,36$ or $42 \mathrm{~h}$.

After maturation of the oocytes the cumulus cells were loosened by incubation for $30-60 \mathrm{~s}$ in $0.25 \%$ trypsin $+0.02 \%$ EDTA to help their removal by pipetting. Chromosome slides were prepared according to the technique developed by Tarkowski (1966).

The meiotic stages of the oocytes were determined according to the description of chromosome configuration by Xu et al (1986) and Suss et al (1988) and modification for horse oocytes by King et al (1990) (fig 1).

Statistical analyses were conducted by means of chi-square analysis. 


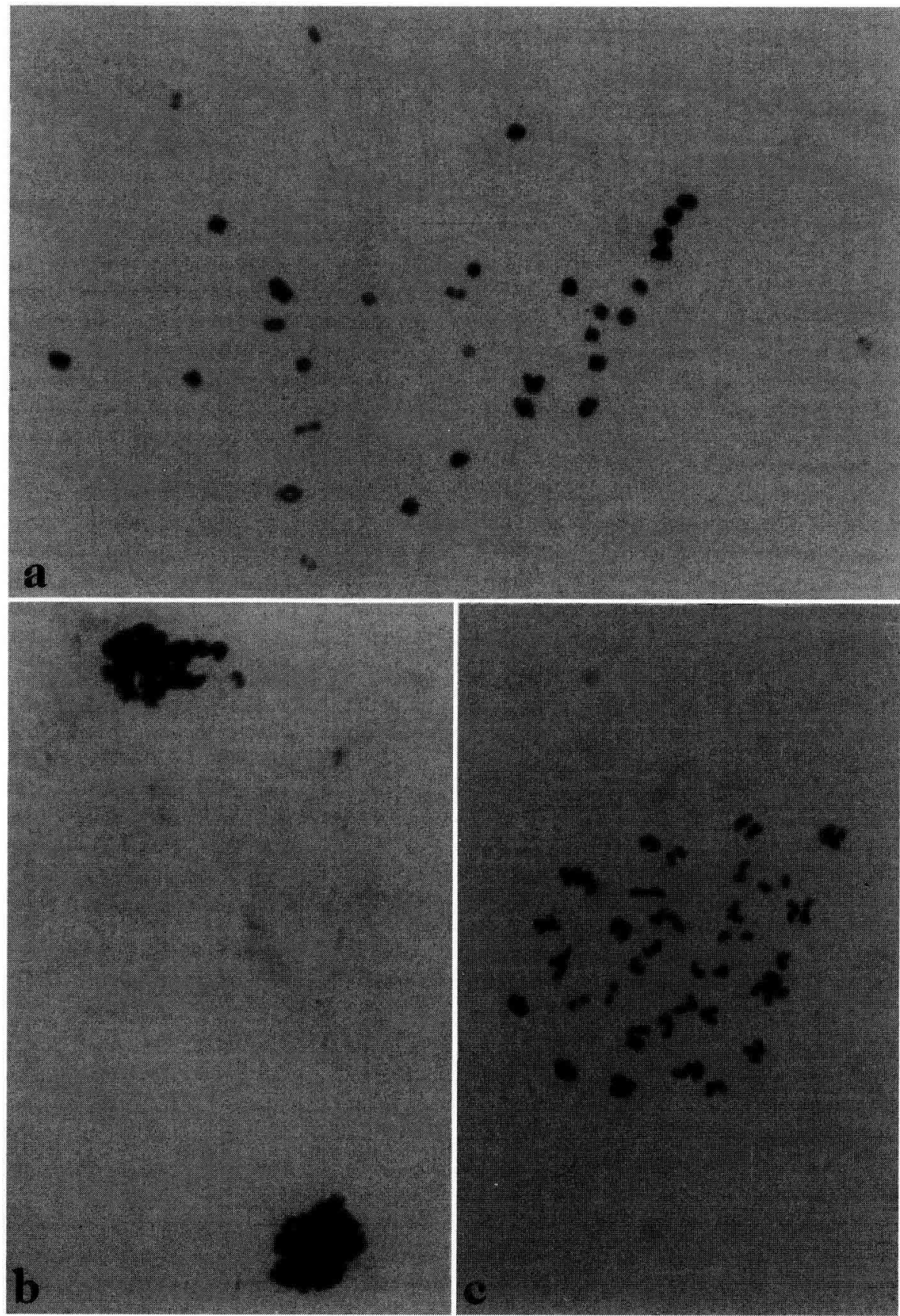

Fig 1. Chromosome slides from oocytes matured in vitro; stages of meiosis: a) first meiotic metaphase (MI) - 32 bivalents; b) first meiotic telophase (TI) - two groups of chromosomes; c) second meiotic metaphase (MII) - 32 chromosomes. 


\section{RESULTS}

A total of 522 oocytes were collected from 221 ovaries (2.4 oocytes per ovary). Among the collected COCs, 271 (51.9\%) out of 522 oocytes were accepted for IVM. The remaining oocytes $(251 / 522,48.1 \%)$ were discarded because i) ooplasm was irregulary clumped or misshapen, ii) only the corona radiata was present and iii) the cumulus cells were expanded and/or pyknotic.

The chromosome slides were prepared from 249 (out of $271,91.9 \%$ ) cells: 170 (out of $249,68.3 \%$ ) of them could be cytogenetically analysed, whereas in 79 spreads $(31.7 \%)$ the analysis was impossible due to the loss of chromosomes during fixation or clumping of chromatin. The stages of meiosis could be recognized in 142 oocytes $(57.0 \%)$. In the remaining $28(11.2 \%)$ the chromosome stages were not determined.

The proportion of oocytes which achieved the nuclear maturation stage within $24 \mathrm{~h}$ was significantly lower $(P<0.05)$ than in the case of oocytes matured for at least $30 \mathrm{~h}$. The percentages of oocytes which reached telophase I or metaphase II in the group matured for 30 , 36 or $42 \mathrm{~h}$ were $70.4,75.0$ and $74.4 \%$, respectively. Chi-square analysis showed that these differences were not significant. The results of cytogenetic analysis are presented in table I.

\section{DISCUSSION}

In the mare the number of oocytes that it is possible to obtain from an ovary is limited by the number of follicles, which is a result of the different structure of the mare's ovaries.

In our study an average of 2.4 oocytes per ovary were recovered by aspiration. The number of oocytes recovered by aspiration from a single ovary in the present study was higher than that presented by Willis et al (1991b), who recovered an average of 1.1-1.7 oocytes and Choi et al (1993), who noted an average of 1.7 oocytes per ovary. A slightly higher number of collected oocytes was reported by Hinrichs (1991) (an average of 2.7 oocytes) and Shabpareh et al (1993) (an average of 3.0-3.7 oocytes per ovary). The low recovery rate of oocytes obtained by using the aspiration technique may be caused by strong adhesion of COCs to the follicular walls inside the ovarian follicles, as already suggested by Shabpareh et al (1993).

In the present study, $51.9 \%$ of the oocytes recovered by aspiration were acceptable for IVM, whereas Choi et al (1993) obtained a slightly lower rate $(34 \%)$ of aspirated oocytes acceptable for IVM. In the same study, 55\% of the oocytes recovered using isolation of follicles were classified for maturation. Similar results were presented by Del Campo et al

Table I. Cytogenetic analysis of horse oocytes matured in vitro for $24,30,36$ or $42 \mathrm{~h}$.

\begin{tabular}{|c|c|c|c|c|c|c|c|c|}
\hline \multirow{3}{*}{$\begin{array}{l}\text { Time } \\
\text { (hours) }\end{array}$} & & \multicolumn{7}{|c|}{ Number of oocytes } \\
\hline & \multirow[t]{2}{*}{ Analysed } & \multicolumn{3}{|c|}{ Unmatured } & \multicolumn{3}{|c|}{ Matured } & \multirow{2}{*}{$\begin{array}{c}\text { Not recognized } \\
\text { stages }(\%)\end{array}$} \\
\hline & & $G V(\%)$ & $M I(\%)$ & Total (\%) & $T I(\%)$ & $M I I(\%)$ & Total (\%) & \\
\hline 24 & 45 & $15(33.3)$ & $3(6.7)$ & $18(40.0)$ & $2(4.4)$ & $17(37.8)$ & $19(42.2)$ & $8(17.8)$ \\
\hline 30 & 27 & $2(7.4)$ & $2(7.4)$ & $4(14.8)$ & 0 & $19(70.4)$ & $19(70.4)$ & $4(14.8)$ \\
\hline 36 & 20 & $2(10.0)$ & 0 & $2(10.0)$ & 0 & $15(75.0)$ & $15(75.0)$ & $3(15.0)$ \\
\hline 42 & 78 & $5(6.4)$ & $1(1.3)$ & $6(7.7)$ & $1(1.3)$ & $57(73.1)$ & $58(74.4)$ & $14(17.9)$ \\
\hline
\end{tabular}

GV: germinal vesicle; MI: first metaphase; TI: first telophase; MII: second metaphase. 
(1992) and Sronina and Okólski (1993): 59 and $65 \%$, respectively.

In domestic animals the time required for oocyte maturation differs among species (Gordon, 1994). Horse oocytes cultured for $15 \mathrm{~h}$ reached nuclear maturity for IVF (telophase I or metaphase II) in $47-48 \%$ of the cases as reported by Willis et al $(1991 \mathrm{~b}, 1994)$. It should be emphasized, however, that in other studies such a short time of IVM resulted in a very low percentage of matured oocytes. In the studies of Hinrichs et al (1993) and Choi et al (1993), only 6.5 and $7 \%$ of oocytes, respectively, reached nuclear maturity for IVF after $16 \mathrm{~h}$ of incubation. Moreover, results presented by Del Campo et al (1995) and Alm and Torner (1994) showed that $18 \mathrm{~h}$ of culture yielded 15 and $34.8 \%$, respectively, of matured horse oocytes only.

In our study, $42.2 \%$ of oocytes reached maturity after $24 \mathrm{~h}$. Similar results were reported by Shabpareh et al (1993); Choi et al (1993) and Alm and Torner (1994), who obtained 48,50 , and $56 \%$ of matured oocytes, respectively. King et al (1990) noted $68 \%$ of matured oocytes after $24 \mathrm{~h}$. Fulka and Okólski (1981), however, showed only $11.2 \%$ of matured oocytes after $24 \mathrm{~h}$ of incubation. These results indicate the high variability of data among studies.

When oocytes were cultured for 30-32 h the majority of oocytes reached maturity. Our result of $70.4 \%$ of matured oocytes compared with results obtained by other investigators as follows: $61 \%$ (Zhang et al, 1989), 62\% (Choi et al, 1993), 72.7\% (Alm and Torner, 1994) and 85.7\% (Shabpareh et al, 1993). A lower result of matured oocytes was presented by Bezard and Palmer (1992) (42\%) and Willis et al (1991a) (52\%).

When the time of maturation was $36 \mathrm{~h}$ or longer, approximately $75 \%$ of the oocytes in our study were matured. Similar results were reported by other investigators: $68.2 \%$ (Fulka and Okólski, 1981), 70\% (Choi et al, 1993) and $84.2 \%$ (Shabpareh et al, 1993). A lower rate of about $46 \%$ of matured oocytes was noted by Del Campo et al (1995).

Oocytes cultured over $48 \mathrm{~h}$ usually displayed degenerate polar bodies and fragmented ooplasm as previously described (Shabpareh et al, 1993).

\section{CONCLUSION}

i) After $30 \mathrm{~h}$ of maturation the majority of cultured horse oocytes reached maturity.

ii) The time required for horse oocytes to be matured is longer than for other domestic species (cattle, goat and sheep).

iii) The results of the present study have shown that is it possible to obtain a high rate of oocytes acceptable for IVM using oocyte aspiration.

\section{REFERENCES}

Alm H, Torner H (1994) In vitro maturation of horse oocytes. Theriogenology 42, 345-349

Berg U, Brem G (1991) In vitro Embryoproduktion aus Oozyten von Ovarien einzelner geschlachteten Kuhe. Ditsch Tierarzl Wschr 98, 77-116

Bezard J, Palmer E (1992) In vitro maturation of horse oocytes from slaughtered ovaries. In: 12th Intern Cong Anim Reprod 315-317

Choi YH, Hochi S, Braun J, Sato K, Oguri N (1993) In vitro maturation of equine oocytes collected by follicle aspiration and by the slicing of ovaries. Theriogenology 40, 959-966

Del Campo MR, Donoso MX, Parrish JJ, Ginther OJ (1990) In vitro fertilization of in vitro matured equine oocytes. Equine Vet Sci 10, 18-22

Del Campo MR, Donoso MX, Parrish JJ, Ginther OJ (1995) Selection of follicles, preculture oocyte evaluation, and duration of culture for in vitro maturation of equine oocytes. Theriogenology 43 , 1141-1153

Fulka J, Okólski A (1981) Culture of horse oocytes in vitro. J Reprod Fertil 61, 213-215

Gordon J (1994) Laboratory Production of Cattle Embryos. CAB International, University Press, Cambridge, UK 
Hinrichs K (1991) The relationship of follicle atresia to follicle size oocyte recovery rate on aspiration and morphology in the mare. Theriogenology 36 , 157-168

Hinrichs K, Schmidt AL, Friedman PP, Selgrath JP, Martin MG (1993) In vitro maturation of horse oocytes: characterization of chromatin configuration using fluorescence microscopy. Biol Reprod 48, 363-370

King WA, Desjardins M, Xu KP, Bousquet D (1990) Chromosome analysis of horse oocytes cultured in vitro. Genet Sel Evol 22, 151-160

Shabpareh V, Squires EL, Seidel GE, Jasko DJ (1993) Methods for collecting and maturing equine oocytes in vitro. Theriogenology 40, 1161-1175

Slonina D, Okólski A (1993) Influence of the granulosa cells and theca interna cells on the in vitro maturation of equine oocytes. Med Wet 49, 324-326 (In Polish with abstract in English)

Sosnowski J, Świtoński M, Lechniak D, Moliński K (1996) Cytogenetic evaluation of in vitro matured bovine oocytes collected from ovaries of individual donors. Theriogenology 45, 865-872

Suss U, Wuthrich K, Stranzinger G (1988) Chromosome configuration and time sequences of the first meiotic division in bovine oocytes matured in vitro. Biol Reprod 38, 871-880

Tarkowski AK (1966) An air drying method for chromosome preparation from mouse eggs. Cytogenetics 5, 394-400

Willis P, Caudle AB, Fayrer-Hosken RA (1991a) Effects of time and hormones on in vitro maturation of equine oocytes. Theriogenology 35, 294

Willis P, Caudle AB, Fayrer-Hosken RA (1991b) Equine oocyte in vitro maturation: influences of sera, time and hormones. Mol Reprod Dev 30, 360368

Willis P, Caudle AB, Fayrer-Hosken RA (1994) Fine structure of equine oocytes matured in vitro. $\mathrm{Mol}$ Reprod Dev 37, 87-92

Zhang JJ, Boyle MS, Allen WR, Galli C (1989) Recent studies on in vivo fertilisation of in vitro matured horse oocytes. Equine Vet $J 8$ (suppl), 101-104

Zhang JJ, Muzs LZ, Boyle MS (1990) In vitro fertilization of horse follicular oocytes matured in vitro. Mol Reprod Dev 26, 361-365

Xu KP, Greve T, Smith S, Hyttel P (1986) Chronological changes of bovine follicular oocyte maturation in vitro. Acta Vet Scand 27, 505-519 